Open Access

\title{
Understanding major dimensions and determinants that help in diffusion \& adoption of product innovation: using AHP approach
}

\author{
Bisma Mannan* (1) and Abid Haleem
}

\author{
* Correspondence: \\ bismamannan@gmail.com \\ Department of Mechanical \\ Engineering, Faculty of Engineering \\ and Technology, Jamia Millia \\ Islamia, New Delhi 110025, India
}

\begin{abstract}
In this global world, diffusion \& adoption of new product innovation have become intricate and involves multifaceted process, as consumers demand a broad range of choices. So, this has generated enthusiasm among researchers and business practitioners while studying and implementing diffusion \& adoption of product innovation.

Even though diffusion \& adoption is known as one of the most important processes of an innovation management, but the literature available in this area is highly fragmented. Therefore, in this paper, we attempt to develop a framework for diffusion \& adoption, which helps in learning and understanding its dimensions and determinants from different perspectives. In this study, AHP has been used to analyse the relative importance and provide a ranking to the dimensions and determinants of product innovation. The findings of this study can help the management, product developers and market professionals in strategic planning and in setting their priorities when there is resource constraint. This study also helps in deciding and prioritising the dimensions and determinants that should be fuse during product development phase.

Keywords: Analytical Hierarchy Process (AHP), Diffusion \& adoption, Factors, Innovation management, Knowledge management, Technology transfer, Product innovation
\end{abstract}

\section{Background}

Innovation has been referred as utilisation of thoughts, ideas, plans and concepts to make economic benefits (Akinboye, 2003). When connected to business administration, innovation is a process of being inventive, executing new strategies to sort out or run an organisation and produce enhanced results (Gates and Cooksey, 1998). In the innovation process, creativity and imagination prompt invention; the first presentation or usage of an invention will be innovation, which leads to adoption; adoption results from the diffusion process (Kumar, Kumar and Haleem, 2014).

Product innovation is a complex and multifaceted process which involves many influential factors not only at an individual level but also at organisational and institutional level. It starts with the design phase and ends with the successful adoption of

(c) The Author(s). 2017 Open Access This article is distributed under the terms of the Creative Commons Attribution 4.0 International License (http://creativecommons.org/licenses/by/4.0/), which permits unrestricted use, distribution, and reproduction in any medium, provided you give appropriate credit to the original author(s) and the source, provide a link to the Creative Commons license, and indicate if changes were made. 
product and having a high degree of consumer satisfaction. This study explains the dynamic relationship between the different process through the input-output model of innovation process shown in Fig. 1.

Rogers (2003) said that the process of diffusion is the spread of new thoughts from its source of creation to its ultimate consumers or adopters. The adoption process is in this way start with the mental procedure through which an individual goes from first finding out about an innovation to a particular selection. The innovation process is inadequate if the creation or the final product is restricted just to the innovator i.e. it is not embraced by others and does not bring change to the refer system (Mannan et al., 2015a, b). So many researchers take an interest in this interdisciplinary field of diffusion and adoption. Highly fragment literature is available which suggest that diffusion \& adoption is one of the most complex processes of innovation management (Kumar, Singh and Haleem, 2014). It requires various inputs like Social system variables, Knowledge management, Human resource, Financial inputs, Technology related inputs, technology transfer, Technical know-how, Production capabilities, ICT Resources, Marketing/Sales inputs including customers' needs/wants, R \& D facilities. In return, it increases Competitiveness, Cost effectiveness, Profitability, Higher market share, Brand image, Revenues and Growth, Customer perception, Product/service performance, Credibility and Innovation success rate. The innovation management process has two type of flows; one is which require only information and the other one is which require material, funds, information, etc. (Kumar, Singh and Haleem, 2015). For efficient information flow, there is a requirement of an appropriate communication channel and a proper selection of the mode of communication. It is conceivable to distinguish several ways to deal with the diffusion of innovation, each one concentrating on the particular

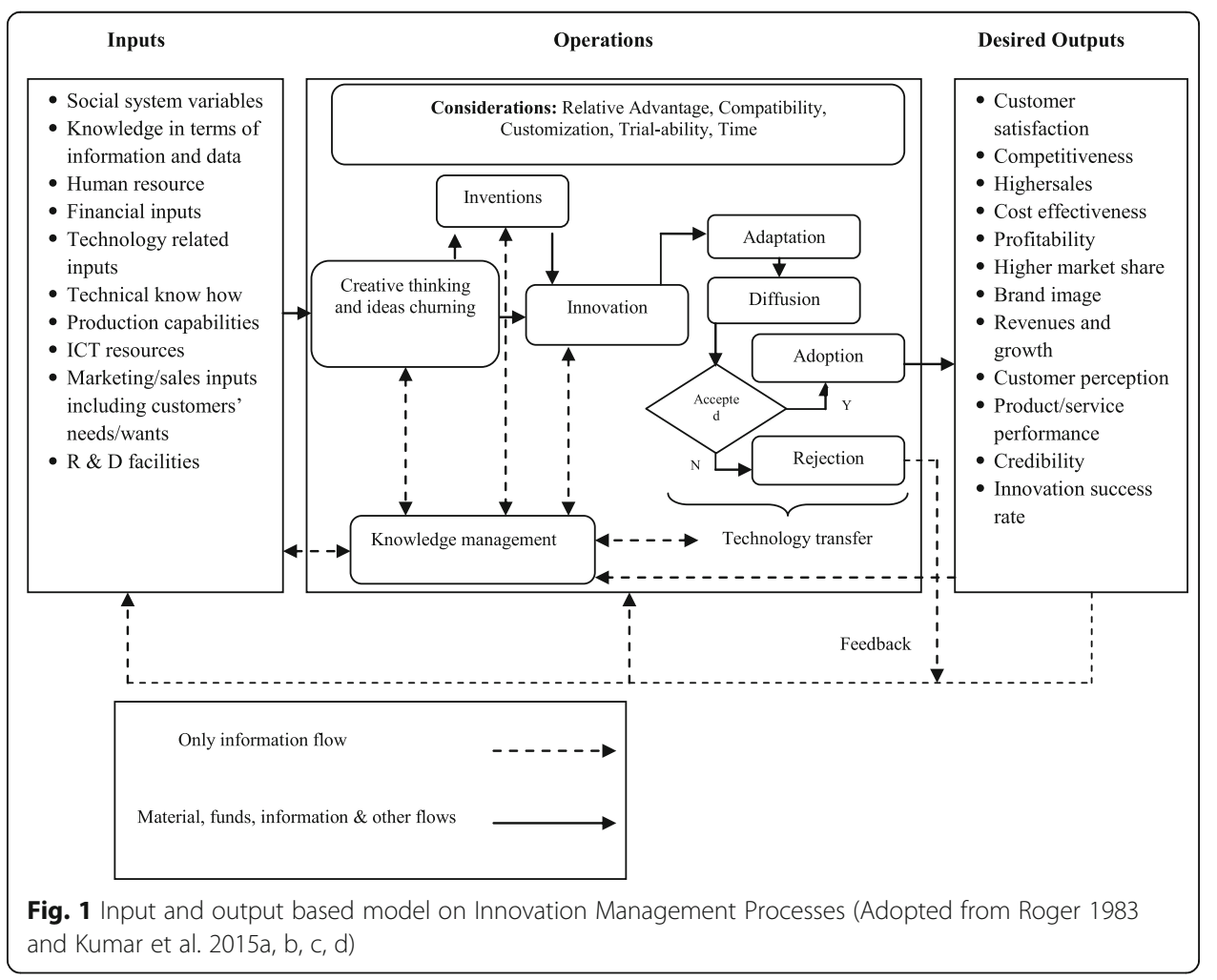


aspect of diffusion and having a different perspective. The fundamental contribution comes from economics, sociology, anthropology, and marketing. Business experts have created different econometric models to clarify the diffusion of new products in the light of the past conduct of the consumers. Geroski (2000) says that business studies have embraced an extensive variety of unique research tools to clarify the customer behaviour. Social studies have been engaged to inspect the socio-consistent element and mental factors that impact the diffusion of innovation, and most of the anthropological studies are base on case studies of the diffusion of new creations, regulations and information. Now, multi-disciplinary research has been developed looking at the diffusion of educational, medicinal and other approaches to innovation. Research on diffusion tries to identify the variables that impact the rate and course of the adoption of innovation.

\section{Research objectives}

This research paper helps to achieve the following objectives:

- Identification of the main dimensions and related determinants helping in diffusion \& adoption of product innovation.

- Prioritisation of the dimensions to develop framework helping in diffusion \& adoption of product innovation.

- Prioritisation of the determinants to develop the framework supporting in diffusion \& adoption of product innovation.

- Global ranking of determinants for successful diffusion \& adoption of product innovation.

- Analysis of the global ranks and local ranks of dimensions and determinants.

This study is to identify and prioritise the determinants that help in diffusion and adoption of product innovation. In this study, Analytical Hierarchy Process (AHP) approach has recommended for prioritising the determinants helping in diffusion \& adoption of product innovation (Saaty, 1980).

The remainder of this paper organised as follows. The state-of-the-art review of related literature covered as well as identified determinants are helping in diffusion and adoption of product innovation based on extensive literature review (Section 2). Section 3 discusses and explains the methodology of the research for the present work. The data analysis has done in Section 4. Discussion, finding and the managerial implication is provided in Section 5. Finally, Section 6 provides conclusions, unique contributions, limitations and the scope for future research.

\section{Literature review}

This section contains the literature on diffusion and adoption of product innovation. The explanation of four dimensions of diffusion \& adoption which is given by Everett M Roger's book titled "Diffusion of innovation" that has more than 77,533 citations is provided. The related determinants/ sub-factors of these dimensions, which helps in diffusion and adoption of product innovation identified and described using literature review approach. Research gaps for this study have been further discussed. 


\section{Diffusion and adoption of product innovation}

Rogers (2003, fifth edition) defines diffusion as "the process by which an innovation is communicated through certain channels over time among the members of a social system".

It is being identified sort of communication that deals with the spread of messages which are view as new thoughts or ideas. Nowadays, information technology (IT) as an example, the Internet and mobile phones which become a part of mass communications and a tool of diffusion. It is the "novelty" of an idea in the message of communication that gives diffusion its unique character. There is a lot of work going on in the area of diffusion \& adoption, and the research status of diffusion and adoption is impressive. In the 1960s and 1970s, the aftereffects of diffusion studies have incorporated in textbooks of public relations, marketing, advertising, social psychology, consumer behaviour and their related areas.

Researches/academicians and practitioners have come together to view the diffusion of product innovation as a significant field of sociology. Numerous U.S. government organisations have a division assigned for diffusing new technologies to local government as well as to the public; examples are the National Institutes of Health, U.S. Department of Transportation, The U.S. Department of Agriculture, and the U.S. Department of Education. Some federal agencies support research on diffusion, for example, the National Science Foundation and various private organisations. Further, most business corporations have a marketing division that is the researcher of diffusing new product and statistical research activities that lead to diffusion to help the organisation's advertising endeavours. Since innovation is happening throughout the society and the application of diffusion \& adoption theory is found in numerous spots. In this way, diffusion $\&$ adoption research has accomplished a prominent position today.

\section{Identification of determinants helping in diffusion \& adoption of product innovation}

Literature review approach has used for identifying determinants helping in diffusion \& adoption of product innovation. Initially, seventeen determinants helping in diffusion \& adoption of product innovation. Further, these identified determinants have been categorised into four dimensions (Innovativeness, Communication channels, Time, and Social system). These identified four dimensions, and related determinants help in diffusion process and determine the success of product innovation have been discussing in detail in below section.

\section{Innovativeness}

Innovation is depicted as a thought, practice, or an object that is view as new by consumers. Numerous analysts concur that the primary success factor of diffusion of innovation is exclusiveness and uniqueness (Pham and Ho 2015; Montazemi and Qahri-Saremi 2015; Winer 2007; Kinnear and Bernhardt, 1990; Cooper 2001). Market analysts have frequently considered consumer acknowledgement of innovation in connection with product innovativeness (Garcia and Calantone, 2002).

Product innovativeness is often identified with the principal innovation qualities (i.e., relative advantage, trialability and compatibility) (Danneels and Kleinschmidtb, 2001). However, (Danneels and Kleinschmidtb, 2001) says that conceptualization of product innovativeness has yet to be establish empirically. There are different points of view in 
the contemporary customer conduct literature (e.g., Hoyer and MacInnis, 2008) typically see factor such as compatibility and trialability as customer learning necessities that impact the speed of diffusion, rather than measurements of innovativeness.

Such interrelated and complex relationships do not often empirically examine in connection to perceived innovativeness. Uniqueness or exclusiveness has been a critical analysis of product innovativeness and has offered as the primary dimension at times (Hoeffler \& Keller, 2003; Rogers, 2003, Valente \& Rogers, 1995; Sanni et al., 2013; Schiffman \& Kanuk, 2004a; 2004b; Singh et al., 2012; Tidd, 2010; Tidd et al., 1997). So, this prompts a definition whereby the level of innovativeness is not a distinct development but rather equals to the degree of originality. The individual meetings with experts recommend that innovativeness is more than uniqueness.

Characteristics of innovativeness that determine success to product innovation and which increase its possibility of successful diffusion and adoption are identifies:

Uniqueness (UQ) Innovation which is unique experience three to five times more success than the innovation which does not stand out (Cooper 2001). However, Hoffman (2005), Lamb et al. (2004), Baker, (1999) note that the changes in the product that already exist and not the unique and radical ones are less risky. Therefore, more chances of having a successful diffusion. In this regard, researchers such as Zikmund \& D’Amico (1993); Kinnear et al. (1995); Winer (2007); Hoffman (2005); Cooper (2001) concur that product innovation achievement relies on upon the accomplishment of making a product that is unique when contrasted with competitors.

Relative advantage (RA) Relative advantage is the extent to which an innovation is seen superior to the other ideas, and it supersedes by specific users, measured in terms that matter to those users, as comfort, economic point of preference, satisfaction or social prestige. The more noteworthy the apparent relative advantage of a product, the quicker its rate of adoption is likely to be. There are no set parameters for what constitutes as "relative advantage". It relies on upon the specific observations and necessities of the consumers.

Compatibility (CB) This is the extent to which a product innovation is seen as predictable and consistent with the qualities, past experiences, and needs of the consumers. An innovation that is inconsistent with the specified conditions, guidelines or practices won't be adopted or received as fast as an innovation that is compatible

Customization (CU) Pine and Gilmore (1999a, 1999b, p. 76) characterise customization as "...producing in light of a specific desire of analysing user." The researchers like Duray (2000a); Pine and Gilmore (1999a, 1999b); Anuar et al. (2014); Chiyangwa and Alexander (2016) said that it is significant to make the refinement in the varieties and customization. While customization takes a stab at satisfying individual user's needs, ranges include more choices from which the user can pick. "In most of the cases, the user doesn't need choices; they exactly want what they specified" (Pine and Gilmore 1999a, 1999b, p. 76). Customization is planned to increase the value of an item since a customised product is well defined according to customer's needs. The client association is a vital issue; since user dictates what the venture needs to create. In 
many cases, product customization can happen ex-post after assembling by the retailer or the users themselves. Also, to roll out procedures adaptable a few improvements on the product development level are necessary. Truth be told, "[t]he idea of modularity is an essential building block in the assembling circumstances customarily thought to be adaptable" (Duray et al. 2000a, p. 610).

Trialability (TB) According to Vasseur and Kemp (2015); El-Gohary (2012); Seyal and Rahman (2003); Stockdale and Standing (2006); Moore and Benbasat (1991); Chiyangwa and Alexander (2016); Sabi et al. (2016); Pham and Ho (2015); Hameed et al. (2012a) said that "Trial-ability is the degree to which an innovation can be tried in a restricted premises." Innovations that can be attempted on the instalment arrangement are embraced quickly than innovations that are not tried. The individual trying-out of advancement is an approach to offer to intend to development, to discover how innovation works under one's particular conditions. This trial is a way to dissipate instability about the new ideas.

Social system (SS)

The diffusion of the new product usually takes place in the social setting frequently referred as a social system. Sometimes in the context of consumer behavior, the term market segment and target market may be used instead of the social system. Rogers (2003) characterised the social framework as "an arrangement of interrelated units occupied with joint critical thinking to achieve a typical objective" (p. 23). Since diffusion of product innovation happens in the social framework or system, it is impacted by the social structure of the social framework. He guaranteed that the nature of the social framework influences people's innovativeness, which is the primary standard for arranging adopters.

The studies on the social system of framework gave by Schiffman et al. (2004a, 2004b); Bakanauskas, (2004); Baker, (2001); Hoffman (2005) express that the related factor of the social system that helps in the accomplishment of diffusion of product innovation relies on:

Attitude towards the change in social system (TC) The social system is dynamic is nature which changes continuously with respect to time. So, there should be a positive attitude towards the change in the technology and the market.

Rational relationships among members of the social system (RR) A rational relationship is a logical relationship among the member of the social system which is based on the reasons and facts rather than on emotions. Many researchers who deal with the consumer behaviour advocate that the rationality among the consumer decide the successful adoption of a product but it's hard to measure it. Sometime users of social system/ target market are emotionally attached or biased towards the certain product.

Level of homogeneity (HL) Uniformity among the members of a social system is neglected by the researchers as a condition for diffusion but in fact, play a fundamental role for social system/ target market. 
Nature and norms characteristic of the social system (NN) Norms are established behaviour patterns for the members of a social system which defines the consumer's compatibility with innovation.

\section{Communication (CM)}

Communication is neither transmission of message nor message itself. It is the mutually shared understanding, beginning with the receiver. Communication should be viable in an association. It is the essence of diffusion and adoption. Indeed, even the basic operation of on organisation can't be performed well without effective communication. It includes the steady stream of information and feedback is an essential part of it. Communication between individuals from the innovation execution group likewise expands the likelihood of fruitful selection of innovation, when colleagues always discuss and communicate about the course of the creation process, conceivable issues and methods for solving those problems. Outside the association, it is between the organisation, its accomplices and shareholders, its delegates and user. Determinants of communication that helps in diffusion and adoption are discussed below:

Mode of communication (MC) Communication has advanced significantly from the times of manual typewriters, telegrams and window placards. According to the researchers, such as; Baker, (1995), Cooper, (1999), Cooper, (2005) Dahnil et al. (2014), Hameed, et al. (2012a), Gopalakrishnan and Bierly (2001) and so forth the newest trend in communication that aids in a diffusion of innovation is social media advertising. That is, the cautious utilisation of social media sites like Facebook, MySpace, YouTube and Twitter to draw the consumer in their trusted network. Buyers make online profiles and organisations make "fan pages" or Twitter accounts that user might "like" or associate with it. The second alternative is email; Internal organisation communication depends on email; in only an era, email has supplanted paper as the mode of communication. The website is additionally one of the options for Critical communication. A few organisations go beyond and utilise their website to host user discussion forums, reports, videos and to post blog

Understandable communication (UC) The interesting point of understandable communication is that individuals will adequately comprehend the message. Consumers need to know how marketers can help them, yet they would not prefer to invest hours making sense of what marketers are attempting to tell them. Clear communication is additionally critical inside the organisation and with the suppliers as well. Only if staff and vendors comprehend messages, then only they will take care of the job effectively. Dahnil et al. (2014), Gopalakrishnan and Damanpour (1994), Hameed et al. (2012a) said that understandable communication is necessary to the success of any organisation. However, it is often left to care for itself in numerous organisations. Understandable and clear communication built trust, reputation, relationship with customers and credibility; and all of these build organisation.

Communication channel (CC) In an association, information flows in every direction i.e. backwards, forward, and sideways. This information alludes as communication. Communication channels mean the way this information flows inside the association and with different organisations. Gopalakrishnan and Damanpour (1994), Dahnil et al. 
(2014), Anuar et al. (2014), Abed et al. (2015), Hameed et al. (2012a) said that if communication channel breakdown, it will prompt a wasteful and insufficient information flow. Employees are unconscious of what the organisation expects of them. They are clueless about what is happening in the organisation. This will make them suspicious of thought processes and any adjustments in the organization. Likewise, without compelling communication channel, employees become division oriented instead of organisation oriented, and this influence decision making and profitability in the working environment.

Communication network (CN) According to Roger (2003), communication network consists of individuals that are interconnected by information flow that follows a pattern which means communication networks helps to create a link in a social system. Communication networking is critical for diffusion because, in an efficient network, the flow of information is smooth and right which take less time.

Time (TM)

In research, the ruling conclusion is that time is the premise of the entire procedure of diffusion and adoption of product innovation. Schiffman et al., 2004a, 2004b research consumer behaviour for a division of adopters. Hoffman et al., 2005; Antonides et al., 1998; Zikmund et al., 1993; Solomon et al., 2002; Schiffman et al. 2004a, 2004b and Lamb et al., 2004 assets of purchasing recurrence. Bakanauskas, 2004 measures adoption rate and all the researchers advocate that time is one of the major factors for diffusion and adoption.

Introduction timing (IT) Introduction timing is frequently a represent the moment of Make-or-Break for small and medium enterprises. Whether, it's a producer working through wholesale and retail outlets, or a retailer attempting to draw in the consumer to innovation. Compelling timing is necessary to pull in new customer and to optimise profit and revenue on innovations. (Klastorin and Tsai, 2004; Regibeau and Rockett, 1996; Srivastava and Lee, 2005; Tony Ke, Max Shen and Li, 2013). In a competitive business sector, the timing and planning of introduction are also influenced by the introduction timing of similar product which is launched by other competitive organisations.

First-mover attempts to pull eager purchasers. Other organisations incline toward a second-mover and wait until the business sector gets comfortable with the item and interest starts to develop. This technique secures against a negative response that may come from the item offered by the first-mover.

Product development cycle (PD) Johnson and Kirchain, 2011 said the article dealing with the assessment of product development is somewhat substantial and concentrates principally on the lead-time metric. Surprisingly, only a few researchers like Chiyangwa and Alexander (2016) and Hameed et al. (2012a) have additionally demonstrated the significance of product development lead-time or cycle as it identifies with product or project achievement.

Progressive Technology (PT) As the time changes, innovation makes obsolete to the existing ones. For example, a smartphone replaces many gadgets which can't 
even count like watches, telephone, camera, personal computers, banking, etc. Adoption rate (AR)

Rogers and Shoemaker (1971) define the rate of adoption as "the relative speed with which an innovation adopted by members of a social system. This rate of adoption is usually measured by the length of time required for a certain percentage of the members of a system to adopt an innovation" (p.28). Anuar et al. (2014), Montazemi and Qahri-Saremi (2015), Gopalakrishnan and Damanpour (1994). Rogers and Shoemaker agree with Toffler (1970) and others that the rate of adoption of innovations is rapidly increasing over a specified period. For instance, they justify the need for their book with the opening statement that "the phenomenal rate at which innovations are invented, developed, and spread makes it important to look at how these new ideas affect (or fail to change) the existing social order (Rogers and Shoemaker 1971, p.1)." But, no evidence is presented to show that the rate of adoption is increasing. All these variables have complied in Table 1 with references.

\section{Research gaps}

Many past research hypotheses advocate that setbacks experienced during diffusion are more prominent than the delays experienced during creation or product development phase. Although it is already established that diffusion and adoption are one of the costliest phases of the innovation process, there is practically no exertion made to develop a framework for diffusion and adoption or learning and understanding its dimensions and determinants from different perspectives. There is no study which deals with the relative importance of diffusion \& adoption dimensions and their correlation with the determinants i.e. in how much weightage these dimension and determinants influences diffusion and adoption of product innovation. Therefore, in this study, AHP is used to analyse the relative importance and provide the ranking to the dimensions and determinants of product innovation. This study helps management, product developers and market professionals in strategic planning and set their priorities when there is resource constraint. It also helps in deciding and prioritising the dimensions and determinants that should be incorporated during product development phase.

\section{Methods}

In this paper, we have taken the four dimensions given by Everett M Roger's book diffusion of innovation which has more than 77,533 citations and which is the second most cited book in social science. Researcher believes that the name of Everett Rogers is virtually synonymous with the study of the diffusion of innovations. The determinants/ sub-factors of dimensions are identified with the help of extensive literature review of most cited paper in the area of diffusion and adoption of innovation. After determining dimension and determinant, we have conducted a workshop in which we sought the opinion of experts on categorising determinants under four well-established dimensions. There are four experts from the management of MSMEs and three from academia. After establishing dimension and determinants, we have used AHP methodology with the help of expert suggestions. Utilisation of AHP methodology helps in accomplishing efficient diffusion and adoption of product innovation and uncovering their significance for the competitiveness of organisations. 
Table 1 Dimensions \& determinants that influence product innovation management with support references

\begin{tabular}{|c|c|c|}
\hline Dimensions & References & Determinants \\
\hline $\begin{array}{l}\text { Innovativeness } \\
\text { (IN) }\end{array}$ & $\begin{array}{l}\text { Zikmund \& D' Amico (1993), } \\
\text { Gopalakrishnan and Damanpour } \\
\text { (1994), Kinnear et al. (1995), Lambkin } \\
\text { (1998), Baker(1999), Cooper(2001), } \\
\text { Tidd (2001), Rogers (2003), Lamb et } \\
\text { al. (2004), Hoffman (2005), Winer } \\
\text { (2007), Solomon (2009), Hameed et } \\
\text { al. (2012a), Rampersad et al. (2012), } \\
\text { Lee (2014), Montazemi and Qahri- } \\
\text { Saremi (2015), Pham and Ho (2015), } \\
\text { Porter and Graham (2015), Wu and } \\
\text { Chiu, (2015), Mannan et al. (2016) } \\
\text { Rogers (2004), Zikmund et al. (2003), } \\
\text { Cooper (2010) }\end{array}$ & $\begin{array}{l}\text { Relative Advantage } \\
\text { (RA) } \\
\text { the clearly seen } \\
\text { benefit provided by } \\
\text { innovation }\end{array}$ \\
\hline
\end{tabular}
References

Kinnear and Bernhardt (1990);

Moore and Benbasat (1991):

Cooper (2001); Winer (2007); El-

Gohary (2012); Hameed et al.

(2012a); Lee (2014);

Gebrezgabher et al. (2015);

Montazemi and Qahri-Saremi

(2015); Vasseur and Kemp

(2015); Chiyangwa and

Alexander (2016); Wang et al. (2016),

Poon and Swatman (1999),

Beatty et al. (2001), Kuan and

Chau (2001), Mirchandani and

Motwani (2001), Mehrtens et al.

(2001), Chwelos, et al. (2001),

Doolin et al. (2003), El-Gohary

(2012), Vasseur and Kemp

(2015), El-Gohary et al. (2009),

Grandon and Pearson (2004),

Al-Qirim (2006), Stockdale and

Standing (2006), Kumar (2015a,

2015b, 2015c, 2015d), Moore

and Benbasat(1991), Chiyangwa

and Alexander (2016), Sabi et

al. (2016), Wang et al. (2016),

Lee (2014), Trang et al. (2016),

Lawson-Body and O'Keefe

(2006), Hameed et al. (2012a),

Al-Qirim (2007), Wu and Chiu (2015)

Compatibility(CB) Vasseur and Kemp (2015), Elcompatible with a Gohary (2012). El-Gohary et al. lifestyle norms, values, (2009), Beatty et al., (2001), and skills of Mirchandani and Motwani consumers (2001), Kumar et al.(2015a, 2015b, 2015c, 2015d), Moore and Benbasat (1991)

Chiyangwa and Alexander (2016), Sabi et al. (2016), Pham and $\mathrm{Ho}$ (2015), Arifin and Frmanzah (2015), Wang et al. (2016), Trang et al. (2016), Damanpour (1996),

Gopalakrishnan and

Damanpour (1994), Hameed et al. (2012a), Rampersad et al.(2012), Wu and Chiu (2015)

Customization(CU) Pine and Gilmore (1999a, Alterable to individual or personal 1999b), Duray et al. (2000a), specifications Hameed et al. (2012a), Anuar et al. (2014), Dedehayir et al. (2014), Noppers et al. (2015),Chiyangwa and Alexander(2016), Sabi et al. (2016), Wang et al. (2016). Chang et al. (2015), Mannan \& Khurana (2012), Khurana et al. (2013), Khurana et al. (2014).

Trial ability (TB) Moore and Benbasat Ability to try out (1991),Seyal and Rahman (2003), El-Gohary (2012), Pham and Ho (2015), Vasseur and Kemp (2015), Chiyangwa and Alexander (2016), Sabi et al. (2016), Stockdale and Standing (2006). 
Table 1 Dimensions \& determinants that influence product innovation management with support references (Continued)

\begin{tabular}{ll}
\hline Social system & Montazemi and Qahri-Saremi (2015), \\
(SS) & Rogers (2003), Vasseur and Kemp \\
& (2015), Venkatesh et al., (2003), \\
& Chiyangwa and Alexander (2016), \\
& Sarpong et al. (2016), Locke and \\
& Rissman (2015), Long et al. (2016), \\
& Montalvo (2008), Shen et al. (2015), \\
& Rai and Robinson (2015), Dahnil et \\
& al. (2014), Brook and Pagnanelli \\
& (2014), Hottenstein et al. (1999), \\
& Hameed et al. (2012a)
\end{tabular}
(CM)
Communication
Rogers (2003), Dahnil et al. (2014), Gopalakrishnan and Damanpour (1994), Hameed et al. (2012a), Mannan, Khan, and Khurana (2012), Mannan, Jameel, and Haleem (2013a),
Attitude towards change (TC) Customer reaction towards change

Venkatesh et al. (2003), Montalvo (2008), Rampersad et al.(2012), Anuar et al. (2014), Lee (2014), Knudsen and Roman (2015), Long et al. (2016),Abed et al.(2015), Porter and Graham (2015), Shen et al. (2015), Chiyangwa and Alexander (2016)

Rational relationships Dahnil et al. (2014), Abed et al. (RR) Reasonable relationship based on the facts

(2015), Locke and Rissman (2015), Montazemi and QahriSaremi (2015), Knudsen and Roman (2015), Long et al. (2016), Rai and Robinson, (2015). Kumar, (2014), Kumar \& Haleem, (2016), Grandon \& Pearson, (2003), Henry \& Kato, (2011), Kapur et al., (2012)

Homogeneity level Venkatesh et al. (2003), (HL) Uniformity of social system Montalvo (2008), Abed et al. (2015), Locke and Rissman (2015), Kusumaningtyas and Suwarto (2015), Porter and Graham (2015), Shen et al. (2015), Rai and Robinson (2015), Sabi et al. (2016).

Nature \& norms (NN) Chang and Cheung (2001), Social and cultural Kuan and Chau (2001) policies of the society Grandon and Pearson (2004), El-Gohary et al. (2009), ElGohary(2012), Crann et al. (2015), Gebrezgabher et al. (2015), Long et al. (2016), Rai and Robinson (2015), Shen et al. (2015).

Mode of Gopalakrishnan and Bierly communication (MC) (2001), Hameed et al. (2012a), Medium of communication

Understandable communication (UD) Easy to understand

Dahnil et al. (2014)

Gopalakrishnan and Damanpour (1994), Hameed et al. (2012a), Dahnil et al. (2014), Kumar, Luthra and Haleem (2015b).

Communication channels (CC) Link of information

Gopalakrishnan and Damanpour (1994), Hameed et al. (2012a), Mannan, Khurana, and Haleem (2012), Mannan, Khan, and Khurana (2013b), Anuar et al.(2014), Dahnil et al. (2014), Abed et al.(2015).

Communication Gopalakrishnan and network (CN) Interact and Damanpour (1994), Hameed et al. (2012a), Dahnil et al. (2014), exchange information Trang et al. (2016), Wang et al. in social system (2016). Khurana et al., (2012), Sambasivan \& Fei, (2008), Noorul Haq \& Kannan, (2006), Pardeshi, (2014)

Rogers (2003), Derwisch et al. (2015), Introduction timing Sarpong et al. (2016),

Gopalakrishnan and Damanpour (1994), Tsai and Hung (2014)

Proper timing of
Regibeau and Rockett, (1996), Klastorin and Tsai (2004), Srivastava and Lee (2005), Tony Ke, Max Shen and Li (2013), Lee (2014).
(IT) introduction of innovation into the market 
Table 1 Dimensions \& determinants that influence product innovation management with support references (Continued)

\begin{tabular}{|c|c|}
\hline $\begin{array}{l}\text { Product } \\
\text { development cycle } \\
\text { (PD) } \\
\text { Time require to } \\
\text { develop an } \\
\text { innovation }\end{array}$ & $\begin{array}{l}\text { Hameed et al. (2012a), Kaushik } \\
\text { et al. (2014), Chiyangwa and } \\
\text { Alexander (2016). Venkatesh et } \\
\text { al., (2002), Walitzer et al., (2015), } \\
\text { Winer, (2000), Zhu et al., (2012) }\end{array}$ \\
\hline $\begin{array}{l}\text { Progressive } \\
\text { Technology (PT) } \\
\text { Innovation making } \\
\text { obsolete to the } \\
\text { existing one with time }\end{array}$ & $\begin{array}{l}\text { Anuar et al. (2014), Lee (2014), } \\
\text { Tsai and Hung (2014), Abed et } \\
\text { al.(2015), Pham and Ho (2015), } \\
\text { Porter and Graham (2015), } \\
\text { Chiyangwa and Alexander } \\
\text { (2016). }\end{array}$ \\
\hline $\begin{array}{l}\text { Adoption rate (AR) } \\
\text { Time require to adopt } \\
\text { innovation }\end{array}$ & $\begin{array}{l}\text { Gopalakrishnan and } \\
\text { Damanpour (1994), Anuar et al } \\
\text { (2014), Montazemi and Qahri- } \\
\text { Saremi (2015). Lamb et al., } \\
\text { (2013), Lucia-Palacios et al., } \\
\text { (2014), Udoh, (2012). }\end{array}$ \\
\hline
\end{tabular}

AHP has been used for this study because of its benefits over other multi-criteria basic making (MCDM) tools, for example, ISM, DEMETEL, ELECTRE, TOPSIS, and ANP. ISM can give the following structure to the reliant variables required in the study yet neglects to examine the relative significance of the variables w.r.t. The objective. Henceforth, it distinguishes the course of the relationship of the variables yet at the same time neglects to perceive their weightage. Other MCDM tools like ELECTRE and TOPSIS has restricted acknowledgement among practitioners and researchers (Mathiyazhagan et al., 2013; Kumar et al., 2015a, 2015b, 2015c, 2015d). Another MCDM tool is ANP which requires a few comparison pair-wise matrices that add complexity to the study for expert members (Harputlugil et al., 2011) as compared with AHP (Mathiyazhagan et al., 2013).

Solving problem utilising AHP can be sorted into the following three broad steps:

Step I: Conversion of decision problem into a hierarchical structure.

In this step, a systematic hierarchical structure was first developed (as shown in Fig. 2) to facilitate the study.

A list of dimensions and determinants for efficient diffusion and adoption are selected through a literature review and a structured hierarchical framework was developed with the help of expert consultation.

Step II: Collection of information and construct a judgmental matrix

This step includes the gathering of information from experts. The experts have examined the strength of dimensions in connection with another dimension positioned on the relative scales in a pair-wise comparison (Saaty, 2000; Saaty, 2008; Lewis et al., 2006). With the assistance of the expert's judgment, an arrangement of correlation matrices was built for all components in a level and then change individual correlation judgments into proportion scale estimations (Kannan et al., 2008).

Step III: Determination of needs by calculation of standardised weights.

After the judgmental matrices are developed, normalised weights of all criteria are figured. The sets of data are not consistent with this situation; subsequently, the researcher of the standardised eigenvector method is recommended for computing relative weights (Saaty, 1996, 2000; Lewis et al., 2006). At that point, the global weight and most extreme 


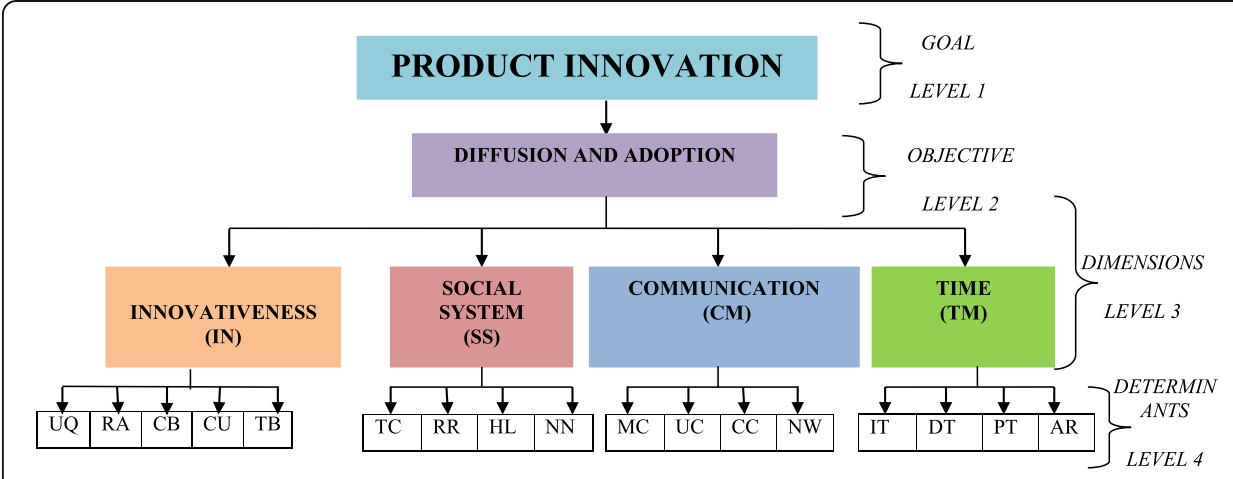

Fig. 2 A hierarchical AHP model of dimensions and determinants for the successful diffusion and adoption of product innovation

Eigen value $(\lambda \max )$ for every matrix are figured. The global priority weights of every hierarchical level can be figured by multiplying a standardized vector to approve the pair-wise correlation matrix gives an entirely reliable assessment (Kannan et al., 2008).

A nine-point scale, as proposed by Saaty (2000) proposed, and is utilised to measure the inclinations. The CR can be figured out by utilising the following formula:

$$
\mathrm{CR}=(\lambda \max -\mathrm{n}) /(\mathrm{n}-1)(\mathrm{RI})
$$

Where the order of matrix is " $\mathrm{n}$ " and "RI" is known as random consistency index. RI values for matrices given in Table 2

\section{Data analysis and results}

There are four main dimensions of diffusion and adoption of product innovation i.e. innovativeness, social system, communication and time. In this study, we have identified various determinants of each dimension. With the help of AHP approach, we have calculated local and global weight and then rank them accordingly

Tables 3, 4, 5, 6 and 7 shows the local priority weights of different factors as generated to determine the relative importance of these dimensions and their determinants with respect to successful diffusion and adoption of product innovation. After that, rankings of the level- 3and level-4 has been done from their global weights (priority percent with respect to the objective) and are represented in Table 8.

The results have been compiled as follows:

From the AHP analysis, it is found out that time is the most critical dimension followed by communication, innovativeness and social system.

- If considering innovativeness as a primary dimension, then the highest local weight is of compatibility followed by relative advantage.

- If considering a social system as the main dimension, then the highest local weight is of rational relationships followed by nature and norms.

Table 2 Average random consistency index (RI) based on critical size 
Table 3 Pairwise comparison matrix of diffusion and adoption dimensions that influences innovation management

\begin{tabular}{lllllll}
\hline $\begin{array}{l}\text { Diffusion and adoption } \\
\text { dimensions }\end{array}$ & $\begin{array}{l}\text { Innovativeness } \\
\text { (IN) }\end{array}$ & $\begin{array}{l}\text { Social system } \\
\text { (SS) }\end{array}$ & $\begin{array}{l}\text { Communication } \\
\text { (CM) }\end{array}$ & $\begin{array}{l}\text { Time } \\
(\mathrm{TM})\end{array}$ & $\begin{array}{l}\text { Priority } \\
\text { weight }\end{array}$ & Rank \\
\hline Innovativeness (IN) & 1 & 2 & $1 / 3$ & $1 / 4$ & 0.124793 & 3 \\
Social system (SS) & - & 1 & $1 / 4$ & $1 / 5$ & 0.0777981 & 4 \\
Communication (CM) & - & - & 1 & $1 / 2$ & 0.305571 & 2 \\
Time (TM) & - & - & - & 1 & 0.491839 & 1 \\
\hline
\end{tabular}

Maximum Eigen Value $=4.04836 ;$ C.I. $=0.0161203$

- If considering communication as a main dimension than the highest local weight is of understandable communication followed by mode of communication.

- If considering time as a main dimension than the highest local weight is of progressive technology followed by adoption rate.

- When considering a global weight then progressive technology, Understandable communication, Adoption rate, Mode of Communication, Introduction timing, Compatibility, Communication channels, Nature \& norms have relative higher weight than other determinants.

\section{Result and discussion}

Due to globalisation, there is a rapid technological change, shorter product life cycles, environment and social issues. Thus, organisation are under tremendous pressure to incorporate changes in their business practices. Confronted with a progressively evolving environment, organisation are now dependably concerned about new product development. This could bring a change ranging from slight to moderate to extensive or the continuum, or even result in absolutely new product offerings. In-spite, new product development gives a competitive advantage to the organisation, but it is also sensible to consider the future longevity of technologies. There two problems that faced by any product innovation organisation are, i) whether the altered/new product would be acknowledged by the consumer(s), and ii) how rapidly would the product be recognised by the consumers(s). While the first relates to what is alluded to as diffusion, the second relates to what is known as adoption. Dissemination and adoption were studied by many researchers like Kotler et al. (2003), Zikmund \& D’Amico (1993), Baker (1999), Kinnear et al. (1995), Winer (2007), Tidd (2001), Cooper (2001) and Hoffman (2005) but the literature is highly fragmented and deals with only a few aspects of it. Although Roger's studies on diffusion and adoption have introduced us with four dimensions of diffusion and adoption. But Roger's studies do not give the information

Table 4 Pairwise comparison matrix of determinants of Innovativeness of diffusion and adoption that influences innovation management

\begin{tabular}{|c|c|c|c|c|c|c|c|}
\hline $\begin{array}{l}\text { Determinants under } \\
\text { "Innovativeness" }\end{array}$ & $\begin{array}{l}\text { Uniqueness } \\
\text { (UQ) }\end{array}$ & $\begin{array}{l}\text { Relative } \\
\text { Advantage } \\
\text { (RA) }\end{array}$ & $\begin{array}{l}\text { Compatibility } \\
\text { (CB) }\end{array}$ & $\begin{array}{l}\text { Customization } \\
(\mathrm{CU})\end{array}$ & $\begin{array}{l}\text { Trial- } \\
\text { ability } \\
\text { (TB) }\end{array}$ & $\begin{array}{l}\text { Priority } \\
\text { weight }\end{array}$ & Rank \\
\hline Uniqueness (UQ) & 1 & $1 / 4$ & $1 / 3$ & $1 / 5$ & 2 & 0.0799396 & 5 \\
\hline $\begin{array}{l}\text { Relative Advantage } \\
\text { (RA) }\end{array}$ & - & 1 & $1 / 5$ & 2 & 5 & 0.266364 & 2 \\
\hline Compatibility(CB) & - & - & 1 & 4 & 6 & 0.418962 & 1 \\
\hline Customization(CU) & - & - & - & 1 & 3 & 0.18301 & 3 \\
\hline Trialability (TB) & _- & _- & _- & _- & 1 & 0.0517252 & 4 \\
\hline
\end{tabular}

Maximum Eigen Value $=5.33199 ;$ C.I. $=0.0829966$ 
Table 5 Pairwise comparison matrix of determinants of Social system of diffusion and adoption that influences innovation management

\begin{tabular}{lllllll}
\hline $\begin{array}{l}\text { Determinants under } \\
\text { "Social system" }\end{array}$ & $\begin{array}{l}\text { Attitude Towards } \\
\text { Change (TC) }\end{array}$ & $\begin{array}{l}\text { Rational } \\
\text { Relationships } \\
\text { (RR) }\end{array}$ & $\begin{array}{l}\text { Homogeneity } \\
\text { level (HL) }\end{array}$ & $\begin{array}{l}\text { Nature } \\
\text { \&Norms } \\
(\mathrm{NN})\end{array}$ & $\begin{array}{l}\text { Priority } \\
\text { weight }\end{array}$ & Rank \\
\hline $\begin{array}{l}\text { Attitude Towards } \\
\text { Change (TC) }\end{array}$ & 1 & 5 & 3 & $1 / 3$ & 0.282984 & 2 \\
$\begin{array}{l}\text { Rational Relationships } \\
\text { (RR) }\end{array}$ & - & 1 & $1 / 3$ & $1 / 6$ & 0.0599547 & 4 \\
$\begin{array}{l}\text { Homogeneity level } \\
\text { (HL) }\end{array}$ & - & - & 1 & $1 / 3$ & 0.141077 & 3 \\
Nature \& Norms (NN) & - & - & - & 1 & 0.515984 & 1 \\
\hline
\end{tabular}

Maximum Eigen Value $=4.16272 ;$ C.I. $=0.0542394$

on (i) how these dimensions can be achieved; (ii) what are the determinants that help in making these dimensions; and (iii) what is the relative significance of these dimensions and determinant. So that decision makers of organisation can set their priority. This study provides an understanding of dimension and determinants for diffusion and adoption of product innovation with the help of AHP.

In this study, we have developed an input and output model of diffusion and adoption using literature review that can be helpful for organisations in identifying the gaps, flow of information and resources between the desired and the current conditions of diffusion and adoption as well as in identifying the areas of improvements. Next, we have taken 4 dimensions of diffusion and adoption given by Rogers (2003) i.e. innovativeness, social system, communication and time which include all the broad aspect of diffusion and adoption. Then with the help of literature review, we have identified 17 determinants of these four dimensions that influence diffusion and adoption of product innovation, and they are compiled in tabular form. After that hierarchical model is developed and this hierarchical model of diffusion and adoption of product innovation can permit managers/ decision-makers to effectively watch the impact of the progressions in the upper levels of the criteria with respect to the lower levels changes. Then we are using AHP approach in which we have done a pair wise comparison of each dimension and their determinants and then calculate their local and global weights. According to calculated weight, local as well as global ranking has been done that shows the relative importance of each dimension and determinants. It will help decision-makers/managers to structure their issue by

Table 6 Pairwise comparison matrix of determinants of Communication of diffusion and adoption that influences innovation management

\begin{tabular}{|c|c|c|c|c|c|c|}
\hline $\begin{array}{l}\text { Determinants } \\
\text { under } \\
\text { "Communication" }\end{array}$ & $\begin{array}{l}\text { Mode of } \\
\text { Communication } \\
\text { (MC) }\end{array}$ & $\begin{array}{l}\text { Understandable } \\
\text { communication } \\
\text { (UD) }\end{array}$ & $\begin{array}{l}\text { Communication } \\
\text { channels (CC) }\end{array}$ & $\begin{array}{l}\text { Communication } \\
\text { Network (CN) }\end{array}$ & $\begin{array}{l}\text { Priority } \\
\text { weight }\end{array}$ & Rank \\
\hline $\begin{array}{l}\text { Mode of } \\
\text { Communication } \\
\text { (MC) }\end{array}$ & 1 & $1 / 2$ & 3 & 5 & 0.310242 & 2 \\
\hline $\begin{array}{l}\text { Understandable } \\
\text { communication } \\
\text { (UD) }\end{array}$ & - & 1 & 4 & 6 & 0.494763 & 1 \\
\hline $\begin{array}{l}\text { Communication } \\
\text { channels (CC) }\end{array}$ & - & - & 1 & 3 & 0.133594 & 3 \\
\hline $\begin{array}{l}\text { Communication } \\
\text { Network (CN) }\end{array}$ & - & - & - & 1 & 0.061401 & 4 \\
\hline
\end{tabular}

Maximum Eigen Value $=4.07878 ;$ C.I. $=0.0262612$ 
Table 7 Pairwise comparison matrix of determinants of Time of diffusion and adoption that influences innovation management

\begin{tabular}{lllllll}
\hline $\begin{array}{l}\text { Determinants under } \\
\text { "Time" }\end{array}$ & $\begin{array}{l}\text { Introduction } \\
\text { timing (IT) }\end{array}$ & $\begin{array}{l}\text { Product } \\
\text { Development cycle } \\
\text { (PD) }\end{array}$ & $\begin{array}{l}\text { Progressive } \\
\text { Technology (PT) }\end{array}$ & $\begin{array}{l}\text { Adoption } \\
\text { rate (AR) }\end{array}$ & $\begin{array}{l}\text { Priority } \\
\text { weight }\end{array}$ & Rank \\
\hline $\begin{array}{l}\text { Introduction timing } \\
\text { (IT) }\end{array}$ & 1 & 4 & $1 / 3$ & $1 / 2$ & 0.179611 & 3 \\
$\begin{array}{l}\text { Product } \\
\begin{array}{l}\text { Development cycle } \\
\text { (PD) }\end{array}\end{array}$ & - & 1 & $1 / 6$ & $1 / 4$ & 0.0632412 & 4 \\
$\begin{array}{l}\text { Progressive } \\
\text { Technology (PT) }\end{array}$ & - & - & 1 & 2 & 0.479702 & 1 \\
Adoption rate (AR) & - & - & - & 1 & 0.277445 & 2
\end{tabular}

Maximum Eigen Value $=4.07101 ;$ C.I. $=0.0236709$

concentrating on its contrasting aspect instead of concentrating on only one or two aspects. Results will be useful especially for SMEs that are experiencing different sorts of asset limitations, as it will help in figuring appropriate strategies for optimum utilisation of resources.

\section{Managerial implications}

Diffusion and adoption of an innovative product not only increases profit for an organization but also emphasise on consumer's demand. It's a unification of the economic as well as social objectives. Following are the managerial insights that emerge from this study and are given in Table 9.

Table 8 Global ranking of determinants for successful diffusion and adoption of product innovation

\begin{tabular}{|c|c|c|c|c|c|c|}
\hline Dimensions & $\begin{array}{l}\text { Relative } \\
\text { weight }\end{array}$ & Determinants & $\begin{array}{l}\text { Local } \\
\text { weight }\end{array}$ & $\begin{array}{l}\text { Local } \\
\text { rank }\end{array}$ & $\begin{array}{l}\text { Global } \\
\text { weight }\end{array}$ & $\begin{array}{l}\text { Global } \\
\text { rank }\end{array}$ \\
\hline \multirow{5}{*}{$\begin{array}{l}\text { Innovativeness } \\
\text { (IN) }\end{array}$} & \multirow[t]{5}{*}{0.124793} & Uniqueness (UQ) & 0.079940 & 4 & 0.0099759 & 15 \\
\hline & & Relative Advantage (RA) & 0.266364 & 2 & 0.0332403 & 9 \\
\hline & & Compatibility (CB) & 0.418962 & 1 & 0.052283 & 6 \\
\hline & & Customization(CU) & 0.18301 & 3 & 0.022838 & 11 \\
\hline & & Trialability (TB) & 0.051725 & 5 & 0.0064549 & 16 \\
\hline \multirow[t]{4}{*}{ Social system (SS) } & \multirow[t]{4}{*}{0.077798} & Attitude towards change (TC) & 0.282984 & 2 & 0.0220156 & 12 \\
\hline & & Rational Relationships (RR) & 0.059955 & 4 & 0.004664 & 17 \\
\hline & & Homogeneity level (HL) & 0.141077 & 3 & 0.010975 & 14 \\
\hline & & Nature \& Norms (NN) & 0.515984 & 1 & 0.040142 & 8 \\
\hline \multirow[t]{4}{*}{$\begin{array}{l}\text { Communication } \\
\text { (CM) }\end{array}$} & \multirow[t]{4}{*}{0.305571} & $\begin{array}{l}\text { Mode of Communication } \\
(\mathrm{MC})\end{array}$ & 0.310242 & 2 & 0.09480 & 4 \\
\hline & & $\begin{array}{l}\text { Understandable } \\
\text { communication(UC) }\end{array}$ & 0.494763 & 1 & 0.151185 & 2 \\
\hline & & $\begin{array}{l}\text { Communication channels } \\
\text { (CC) }\end{array}$ & 0.133594 & 3 & 0.04082 & 7 \\
\hline & & Networking (NW) & 0.061401 & 4 & 0.01876 & 13 \\
\hline \multirow[t]{4}{*}{ Time (TM) } & \multirow[t]{4}{*}{0.491839} & Introduction timing (IT) & 0.179611 & 3 & 0.088339 & 5 \\
\hline & & Development time (DT) & 0.063241 & 4 & 0.031104 & 10 \\
\hline & & Progressive Technology (PT) & 0.479702 & 1 & 0.23593 & 1 \\
\hline & & Adoption rate (AR) & 0.277445 & 2 & 0.13645 & 3 \\
\hline
\end{tabular}




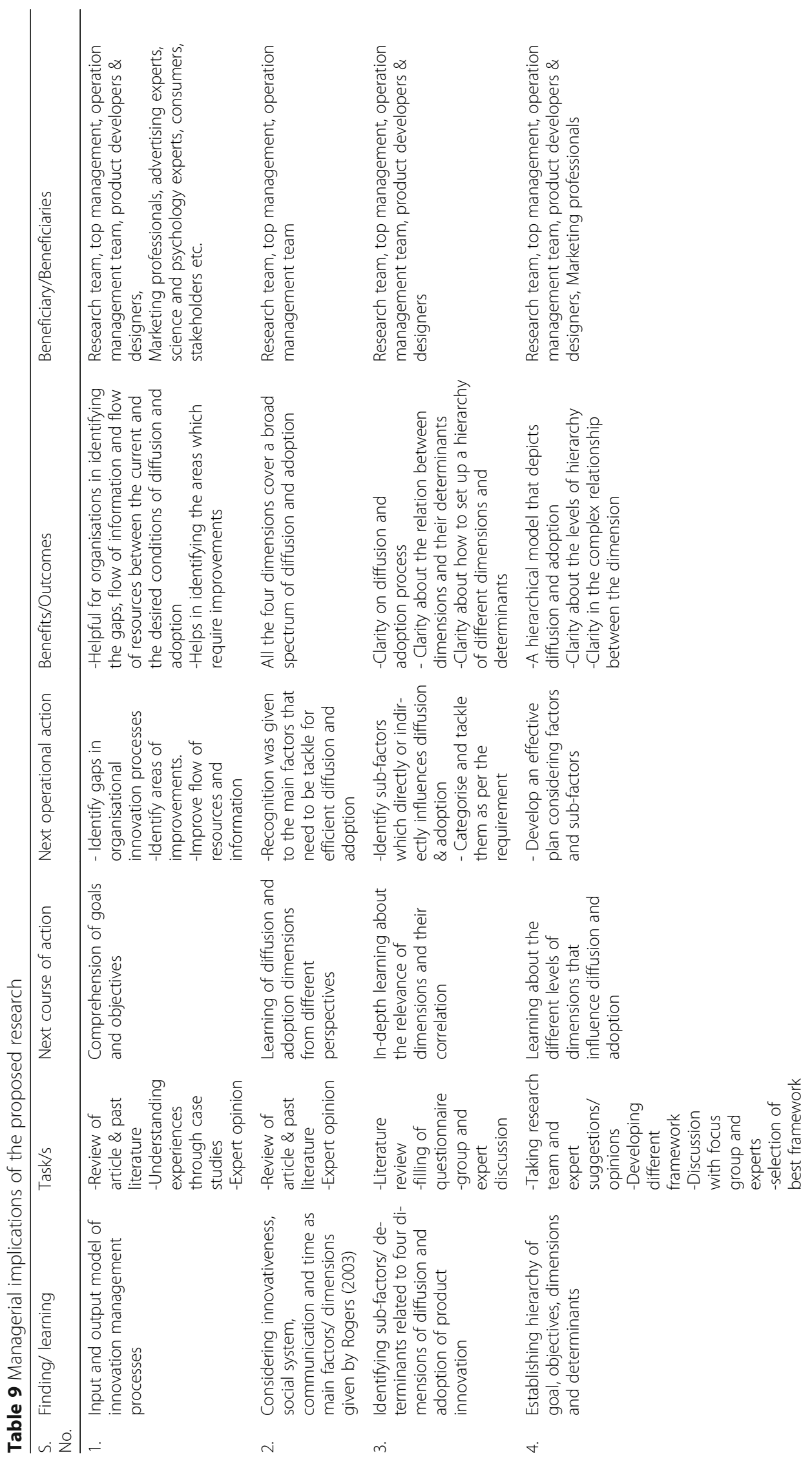




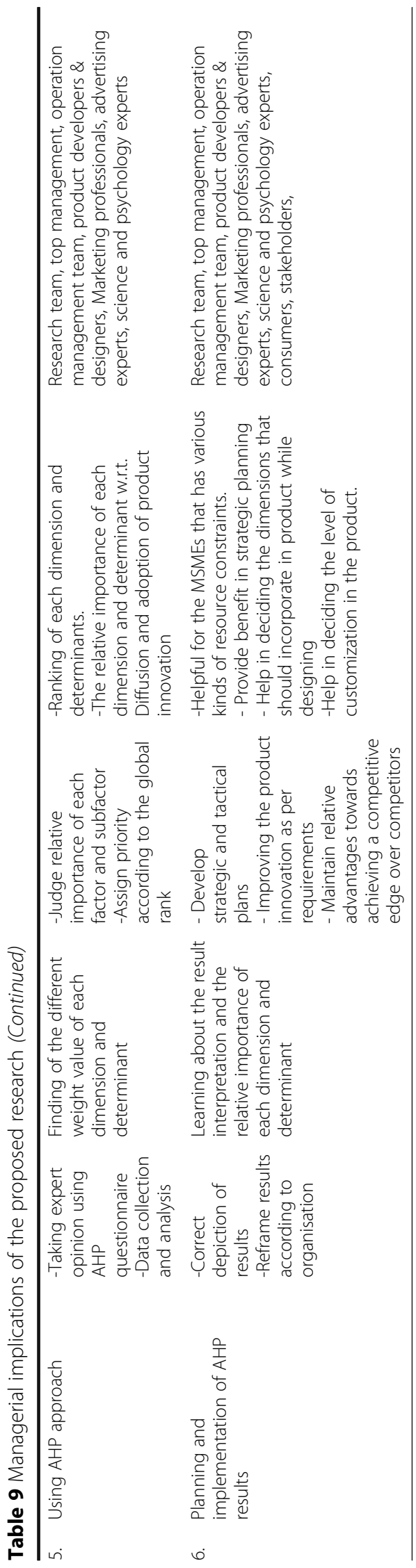




\section{Conclusions}

It's already established that diffusion and adoption is one of the most critical stages of product innovation. So, this study proposed a comprehensive framework to identify dynamics of diffusion and adoption issues from four different perspectives, namely, innovativeness, social system, communication and time. In this study, we have identified 17 sub-factors of these four dimensions/ issues which are justified from the references of different studies as given in Table 1.

An AHP (MCDM technique) has been proposed in this study to recognise the relative significance of different dimensions and determinants that are important for the diffusion and adoption of product innovation. It is found that compatibility and relative advantage have higher weights when considering innovativeness, rational relationship and nature and norms have higher weight when considering the social system, understandable communication and mode of communication when considering communication, progressive technology and adoption rate have higher weight when considering time. When considering global weights then progressive technology, Understandable communication, Adoption rate, Mode of Communication, Introduction timing, Compatibility, Communication channels, Nature \& Norms have relative higher weights than other determinants. Therefore, an organization should give priority to these determinants and aligned their objectives while considering these dimensions and determinants which help in overall diffusion and adoption of product innovation.

\section{Limitations and scope for future research}

Seventeen major determinants Critical in this study under four major dimensions; hence, more determinants can be considered in future research. These determinants will have regional biases. The experts were from northern India, and we assume that their opinion is valid for the industry. For further validation, statistical techniques could be used for these determinants. Also, AHP has the constraint of capturing vagueness which is associated with the judgments of experts. So, fuzzy AHP which can give an opportunity to the experts to express their experiences through natural language can also be considered in future studies.

\section{Acknowledgement}

The authors extend thanks to Dr. Sanjay Kumar, Dr. Sunil Luthra and anonymous experts for sparing their precious time and giving useful comments and suggestions that helped in improving the quality of research. The authors would also like to acknowledge Jamia Millia Islamia and MoMA, Govt. of India for funding this research through MANF (Maulana Azad National Fellowship).

Authors' contributions

$\mathrm{BM}$ is pursuing her doctoral research under the guidance of AH. AH develops a framework, design a questionnaire and finalize the dimensions and determinants with the help of experts. Under his guidance BM collects, analyze and interpret the data. Both authors read and approved the final manuscript. 
Received: 2 August 2016 Accepted: 25 May 2017

Published online: 16 June 2017

\section{References}

Abed, S., Dwivedi, Y., \& Williams, M. (2015). Social media as a bridge to e-commerce adoption in SMEs: a systematic literature review. The Marketing Review, 15(1), 39-57 http://dx.doi.org/10.1362/146934715x14267608178686.

Akinboye, J. O. (2003). Creativity, Innovation and Success. Ibadan: Stirling-Horden Publishers Nig. Ltd.

Al-Qirim, N. (2006). Personas of E-Commerce Adoption in Small Businesses in New Zealand. Journal of Electronic Commerce in Organizations, 4(3), 18-45 http://dx.doi.org/10.4018/jeco.2006070102.

Al-Qirim, N. (2007). A Research Trilogy into E-Commerce Adoption in Small Businesses in New Zealand. Electronic Markets, 17(4), 263-285 http://dx.doi.org/10.1080/10196780701635872

Antonides, G., \& Raaij, W. (1998). Consumer behaviour (1st ed.). New York: Wiley.

Anuar, J., Musa, M., \& Khalid, K. (2014). Smartphone's Application Adoption Benefits Using Mobile Hotel Reservation System (MHRS) among 3 to 5-star City Hotels in Malaysia. Procedia - Social and Behavioral Sciences, 130, 552-557 http://dx.doi.org/10.1016/j.sbspro.2014.04.064.

Arifin, Z., \& Frmanzah. (2015). The Effect of Dynamic Capability to Technology Adoption and its Determinant Factors for Improving Firm's Performance; Toward a Conceptual Model. Procedia - Social and Behavioral Sciences, 207, 786-796 http://dx.doi.org/10.1016/j.sbspro.2015.10.168.

Bakanauskas, A. (2004). Romimas ir integruota marketingo komunikacija. Marketingo komunikacija. Kaunas: VDU.

Baker, M. (1995). Companion encyclopedia of marketing. London: Routledge.

Baker, M. (1999). The IEBM encyclopedia of marketing. London: International Thomson Business.

Baker, A., Boggs, T., \& Lewin, T. (2001). Randomized controlled trial of brief cognitive-behavioural interventions among regular users of amphetamine. Addiction, 96(9), 1279-1287 http://dx.doi.org/10.1046/j.1360-0443.2001.96912797.x.

Beatty, R., Shim, J., \& Jones, M. (2001). Factors influencing corporate web site adoption: a time-based assessment. Information Management, 38(6), 337-354 http://dx.doi.org/10.1016/s0378-7206(00)00064-1.

Brook, J., \& Pagnanelli, F. (2014). Integrating sustainability into innovation project portfolio management-A strategic perspective. Journal of Engineering and Technology Management, 34, 46-62 http://dx.doi.org/10.1016/j.jengtecman. 2013.11.004.

Chang, M. K., \& Cheung, W. (2001). Determinants of the intention to use Internet/WWW at work: a confirmatory study. Information and Management, 39(1), 1-14.

Chang, A., Ismail, I., \& Wahid, N. (2015). A Conceptual Framework on the Social Media Adoption Among Small and Medium Enterprises Managers in Indonesia. Advanced Science Letters, 21(4), 984-988 http://dx.doi.org/10.1166/asl. 2015.5959.

Chiyangwa, T., \& Alexander, P. T. (2016). Rapidly co-evolving technology adoption and diffusion models. Telematics and Informatics, 33(1), 56-76 http://dx.doi.org/10.1016/j.tele.2015.05.004.

Chwelos, P., Benbasat, I., \& Dexter, A. (2001). Research Report: Empirical Test of an EDI Adoption Model. Information Systems Research, 12(3), 304-321 http://dx.doi.org/10.1287/isre.12.3.304.9708.

Cooper, R. (1999). The Invisible Success Factors in Product Innovation. Journal of Product Innovation Management, 16(2), 115-133 http://dx.doi.org/10.1111/1540-5885.1620115.

Cooper, R. (2001). Excelling under pressure: increasing your energy for leadership and innovation in a world of stress, change and unprecedented opportunities. Strategy \& Leadership, 29(4), 15-20 http://dx.doi.org/10.1108/ eum0000000005751.

Cooper, R. (2005). Product leadership. New York: Basic Books.

Cooper, J. (2010). Promoting innovation. Gastrointestinal Nursing, 8(4), 5-5 http://dx.doi.org/10.12968/gasn.2010.8.4.48066.

Crann, S., Fairley, C., Badulescu, D., Mohn, W., \& O’Doherty, K. (2015). Soils, microbes, and forest health: A qualitative analysis of social and institutional factors affecting genomic technology adoption. Technology in Society, 43, 1-9 http://dx.doi.org/10.1016/j.techsoc.2015.06.001.

Dahnil, M., Marzuki, K., Langgat, J., \& Fabeil, N. (2014). Factors Influencing SMEs Adoption of Social Media Marketing. Procedia - Social and Behavioral Sciences, 148, 119-126 http://dx.doi.org/10.1016/j.sbspro.2014.07.025.

Damanpour, F. (1996). Organizational Complexity and Innovation: Developing and Testing Multiple Contingency Models. Management Science, 42(5), 693-716 http://dx.doi.org/10.1287/mnsc.42.5.693.

Danneels, E., \& Kleinschmidtb, E. (2001). Product innovativeness from the firm's perspective: Its dimensions and their relation with project selection and performance. Journal of Product Innovation Management, 18(6), 357-373 http:// dx.doi.org/10.1111/1540-5885.1860357.

Dedehayir, O., Nokelainen, T., \& Makinen, S. (2014). Disruptive innovations in complex product systems industries: A case study. Journal of Engineering and Technology Management, 33, 174-192 http://dx.doi.org/10.1016/j.jengtecman. 2014.06.002.

Derwisch, S., Morone, P., Troger, K., \& Kopainsky, B. (2015). Investigating the drivers of innovation diffusion in a low income country context. Futures: The case of adoption of improved maize seed in Malawi http://dx.doi.org/10.1016/j.futures. 2015.08.011.

Doolin, B., McLeod, L., McQueen, B., \& Watton, M. (2003). Internet Strategies for Established Retailers: Four New Zealand Case Studies. Journal of Information Technology Case and Application Research, 5(4), 3-20 http://dx.doi.org/10.1080/ 15228053.2003 .10856030$.

Duray, R., Ward, P., Milligan, G., \& Berry, W. (2000a). Approaches to mass customization: configurations and empirical validation. Journal of Operations Management, 18(6), 605-625 http://dx.doi.org/10.1016/s0272-6963(00)00043-7.

El-Gohary, H. (2012). Factors affecting E-Marketing adoption and implementation in tourism firms: An empirical investigation of Egyptian small tourism organisations. Tourism Management, 33(5), 1256-1269 http://dx.doi.org/10. 1016/j.tourman.2011.10.013.

El-Gohary, H., Trueman, M., \& Fukukawa, K. (2009). The impact of e-marketing practices on market performance of small business enterprises. critical of Bradford. 
Garcia, R., \& Calantone, R. (2002). A critical look at technological innovation typology and innovativeness terminology: a literature review. Journal of Product Innovation Management, 19(2), 110-132 http://dx.doi.org/10.1111/1540-5885. 1920110.

Gates, G., \& Cooksey, R. (1998). Learning to manage and managing to learn. Journal of Workplace Learning, 10(1), 5-14 http://dx.doi.org/10.1108/13665629810370003.

Gebrezgabher, S., Meuwissen, M., Kruseman, G., Lakner, D., \& Oude Lansink, A. (2015). Factors influencing adoption of manure separation technology in the Netherlands. Journal of Environmental Management, 150, 1-8 http://dx.doi. org/10.1016/j.jenvman.2014.10.029.

Geroski, P. (2000). Models of technology diffusion. Research Policy, 29(4-5), 603-625 http://dx.doi.org/10.1016/s00487333(99)00092-x

Gopalakrishnan, S., \& Bierly, P. (2001). Analyzing innovation adoption using a knowledge-based approach. Journal of Engineering and Technology Management, 18(2), 107-130 http://dx.doi.org/10.1016/s0923-4748(01)00031-5.

Gopalakrishnan, S., \& Damanpour, F. (1994). Patterns of generation and adoption of innovation in organisations: Contingency models of innovation attributes. Journal of Engineering and Technology Management, 11(2), 95-116 http://dx.doi.org/10.1016/0923-4748(94)90001-9.

Grandon, E., \& Pearson, J. (2003). Strategic Value and Adoption of Electronic Commerce: An Empirical Study of Chilean Small and Medium Businesses. Journal of Global Information Technology Management, 6(3), 22-43 http://dx.doi.org/ 10.1080/1097198x.2003.10856354

Grandon, E., \& Pearson, J. (2004). Electronic commerce adoption: an empirical study of small and medium US businesses. Information \& Management, 42(1), 197-216 http://dx.doi.org/10.1016/j.im.2003.12.010.

Hameed, M., Counsell, S., \& Swift, S. (2012a). A conceptual model for the process of IT innovation adoption in organisations. Journal of Engineering and Technology Management, 29(3), 358-390 http://dx.doi.org/10.1016/j. jengtecman.2012.03.007.

Harputlugil, T., Prins, M., Gultekin, T., \& Topcu, I. (2011). Conceptual framework for potential implementations of Multi Criteria Decision Making (MCDM) methods for design quality assessment. In Management and Innovation for a Sustainable Built Environment, Amsterdam, The Netherlands.

Henry, M., \& Kato, Y. (2011). An assessment framework based on social perspectives and Analytic Hierarchy Process: A case study on sustainability in the Japanese concrete industry. Journal of Engineering and Technology Management, 28(4), 300-316 http://dx.doi.org/10.1016/j.jengtecman.2011.06.006.

Hoeffler, S., \& Keller, K. (2003). The marketing advantages of strong brands. Journal of Brand Management, 10(6), 421445 http://dx.doi.org/10.1057/palgrave.bm.2540139.

Hoffman, K. (2005). Marketing principles and best practices. Mason: Thomson/South-Western.

Hottenstein, M., Casey, M., \& Dunn, S. (1999). The diffusion of advanced manufacturing technology in multiplant, multidivisional corporations. Journal of Engineering and Technology Management, 16(2), 129-146 http://dx.doi.org/ 10.1016/s0923-4748(99)00002-8.

Hoyer, W. D., \& MacInnis, D. J. (2008). Consumer Behavior (5th ed.) South-western.

Johnson, M., \& Kirchain, R. (2011). The importance of product development cycle time and cost in the development of product families. Journal of Engineering Design, 22(2), 87-112 http://dx.doi.org/10.1080/09544820902960058.

Kannan, G., Haq, A., \& Sasikumar, P. (2008). An application of the Analytical Hierarchy Process and Fuzzy Analytical Hierarchy Process in the selection of collecting centre location for the reverse logistics Multicriteria DecisionMaking supply chain model. International Journal Of Management And Decision Making, 9(4), 350 http://dx.doi.org/ 10.1504/ijmdm.2008.019360.

Kapur, P., Chaudhary, K., Aggarwal, A., \& Jha, P. (2012). On the development of innovation diffusion model using stochastic differential equation incorporating change in the adoption rate. International Journal of Operational Research, 14(4), 472 http://dx.doi.org/10.1504/ijor.2012.047516.

Kaushik, A., Kumar, S., Luthra, S., \& Haleem, A. (2014). Technology transfer: enablers and barriers - a review. IJTPM, 14(2), 133 http://dx.doi.org/10.1504/ijtpm.2014.060152.

Khurana, S., Khan, J., \& Mannan, B. (2012). Enablers and barriers for implementing technology transfer projects: A study of SMEs in India. Emerging paradigms in marketing. In National conference on emerging paradigms in marketing. New Delhi: JMI http://dx.doi.org/10.13140/RG.2.1.1458.9686.

Khurana, S., Khan, J., \& Mannan, B. (2013). A study on technology management: Enablers and barriers in its implementation in the case of SMEs in India, sustainability and development. In International Conference on Rural Innovation, Capacity Building, Knowledge Management, Entrepreneurship and Technology (ICRICKET). New Delhi: Bloomsbury Publishing http://dx.doi.org/10.13140/RG.2.1.4397.4640.

Khurana, S., Mannan, B., \& Haleem, A. (2014). Integrating innovation with sustainability: A study of practices/status for Indian manufacturing industries (SMEs). In AGBA 11th World Congress Conference. Delhi: IIT http://dx.doi.org/10. 13140/RG.2.1.2824.6005.

Kinnear, T., \& Bernhardt, K. (1990). Principles of marketing. Glenview: Scott, Foresman/Little, Brown Higher Education.

Kinnear, T. C., Bernhardt, K. L., \& Krentler, K. A. (1995). Principles of Marketing (4th ed.). New York: Harper Collins.

Klastorin, T., \& Tsai, W. (2004). New Product Introduction: Timing, Design, and Pricing. Manufacturing \& Service Operations Management, 6(4), 302-320 http://dx.doi.org/10.1287/msom.1040.0050.

Knudsen, H., \& Roman, P. (2015). Innovation Attributes and Adoption Decisions: Perspectives from Leaders of a National Sample of Addiction Treatment Organizations. Journal of Substance Abuse Treatment, 49, 1-7 http://dx.doi.org/10. 1016/j.jsat.2014.08.003.

Kotler, P., \& Trias de Bes, F. (2003). Lateral marketing (1st ed.). Hoboken: Wiley.

Kuan, K., \& Chau, P. (2001). A perception-based model for EDI adoption in small businesses using a technology organization environment framework. Information Management, 38(8), 507-521 http://dx.doi.org/10.1016/s0378 7206(01)00073-8.

Kumar, S. (2014). Contextual interactions analytic hierarchy process (CIAHP): introduction and application to analyse interactions among knowledge management implementation capability (KMIC) factors. International Journal of Knowledge and Learning, 9(3), 242 http://dx.doi.org/10.1504/ijkl.2014.068926. 
Kumar, S., \& Haleem, A. (2016). Benchmarking using an index for bullwhip effect mitigation. 10.5267/J.Uscm, 161-170. http://dx.doi.org/10.5267/j.uscm.2015.10.002

Kumar, S., Kumar, N., \& Haleem, A. (2014a). Contributions in research in the field of innovation management: analysis of critical success factors, benefits and risks. International Journal Of Quality And Innovation, 2(3/4), 310 http://dx.doi. org/10.1504/ijqi.2014.066386

Kumar, S., Kumar, N., \& Haleem, A. (2015c). Conceptualisation of Sustainable Green Lean Six Sigma: an empirical analysis. International Journal of Business Excellence, 8(2), 210 http://dx.doi.org/10.1504/ijbex.2015.068211.

Kumar, S., Luthra, S., \& Haleem, A. (2015b). Benchmarking supply chains by analyzing technology transfer critical barriers using AHP approach. Benchmarking: An International Journal, 22(4), 538-558 http://dx.doi.org/10.1108/bij-05-20140040 .

Kumar, S., Luthra, S., Haleem, A., Mangla, S., \& Garg, D. (2015a). Identification and evaluation of critical factors to technology transfer using AHP approach. International Strategic Management Review, 3(1-2), 24-42 http://dx.doi. org/10.1016/j.ism.2015.09.001.

Kumar, S., Singh, V., \& Haleem, A. (2014b). Knowledge management-enablers and barriers: a questionnaire-based study. International Journal of Knowledge Engineering And Data Mining, 3(1), 31 http://dx.doi.org/10.1504/ijkedm.2014. 066233.

Kumar, S., Singh, V., \& Haleem, A. (2015d). Critical success factors of knowledge management: modelling and comparison using various techniques. International Journal of Industrial and Systems Engineering, $21(2), 180$ http:// dx.doi.org/10.1504/ijise.2015.071508.

Kusumaningtyas, N., \& Suwarto, D. (2015). ICT Adoption, Skill and Use Differences among Small and Medium Enterprises Managers Based on Demographic Factors. Procedia - Social and Behavioral Sciences, 169, 296-302.

Lamb, C., Hair, J., \& McDaniel, C. (2013). Marketing. Mason: South-Western/Cengage Learning.

Lamb, R., Kirby, K., Morral, A., Galbicka, G., \& Iguchi, M. (2004). Improving contingency management programs for addiction. Addictive Behaviors, 29(3), 507-523 http://dx.doi.org/10.1016/j.addbeh.2003.08.021.

Lambkin, M. (1998). European perspectives on consumer behaviour. London: Prentice Hall.

Lawson-Body, A., \& O'Keefe, T. (2006). Interorganizational Relationships in the Context of SMEs' B2B E-Commerce. Journal of Electronic Commerce in Organizations, 4(4), 1-28 http://dx.doi.org/10.4018/jeco.2006100101.

Lee, S. (2014). Examining the factors that influence early adoptersâ $€^{\mathrm{TM}}$ smartphone adoption: The case of college students. Telematics and Informatics, 31(2), 308-318 http://dx.doi.org/10.1016/j.tele.2013.06.001.

Lewis, W., Fai Pun, K., \& Lalla, T. (2006). Empirical investigation of the hard and soft criteria of TQM in ISO 9001 certified small and medium sized enterprises. International Journal of Quality \& Reliability Management, 23(8), 964-985 http:// dx.doi.org/10.1108/02656710610688167.

Locke, C., \& Rissman, A. (2015). Factors influencing zoning ordinance adoption in rural and exurban townships. Landscape and Urban Planning, 134, 167-176 http://dx.doi.org/10.1016/j.landurbplan.2014.10.002.

Long, T., Blok, V., \& Coninx, I. (2016). Barriers to the adoption and diffusion of technological innovations for climatesmart agriculture in Europe: evidence from the Netherlands, France, Switzerland and Italy. Journal of Cleaner Production, 112(1), 9-21 http://dx.doi.org/10.1016/j.jclepro.2015.06.044.

Lucia-Palacios, L., Bordonaba-Juste, V., Polo-Redondo, Y., \& Gronhagen, M. (2014). Technological opportunism effects on IT adoption, intra-firm diffusion and performance: Evidence from the U.S. and Spain. Journal of Business Research, 67(6), 1178-1188 http://dx.doi.org/10.1016/j.jbusres.2013.05.004.

Mannan, B., Jameel, S., \& Haleem, A. (2013a). Knowledge management in project management. Saarbrücken: LAP LAMBERT Academic Publishing http://dx.doi.org/10.13140/RG.2.1.4921.7527.

Mannan, B., Khan, J., \& Khurana, S. (2012b). Informationtechnology: A green supply chain enable emerging paradigms in marketing. In National conference on emerging paradigms in marketing. New Delhi: JMI http://dx.doi.org/10. 13140/RG.2.1.3556.1205

Mannan, B., Khan, J., \& Khurana, S. (2013b). Enablers and barriers to KM in project based organization, sustainability and development. In International Conference on Rural Innovation, Capacity Building, Knowledge Management, Entrepreneurship and Technology (ICRICKET). New Delhi: Bloomsburry Publishing http://dx.doi.org/10.13140/RG.2.1. 3873.1762.

Mannan, B., \& Khurana, S. (2012). Enablers and barriers forintroduction of robotics as an AMT in the Indian industries (case of SME's). International Journal of Computer Applications, 2, 19-24 http://dx.doi.org/10.13140/2.1.2625.5368.

Mannan, B., Khurana, S., \& Haleem, A. (2012a). Identification and analysis of critical factors of KM in project management: An interpretive structural modeling approach. In XVI Annual International conference of Society of Operation Management. Delhi: IIT Lucknow: IIM http://dx.doi.org/10.13140/RG.2.1.1776.0240.

Mannan, B., Khurana, S., \& Haleem, A. (2015a). Study of factors that influences Diffusion and Adoption in Innovation Management. National Seminar on Solar Robotics. Delhi: JMI.

Mannan, B., Khurana, S., \& Haleem, A. (2015b). Technological Innovation challenges and opportunities in India and the developing countries. Annual IEEE India Conference (INDICON), 2015, 1-6 http://dx.doi.org/10.1109/INDICON.2015. 7443854.

Mannan, B., Khurana, S., \& Haleem, A. (2016). Modeling of critical factors for integrating sustainability with innovation for Indian small- and medium-scale manufacturing enterprises: An ISM and MICMAC approach. Cogent Business and Management, 3(1), 1-15 http://dx.doi.org/10.1080/23311975.2016.1140318.

Mathiyazhagan, K., Govindan, K., \& Noorul Haq, A. (2013). Pressure analysis for green supply chain management implementation in Indian industries using analytic hierarchy process. International Journal of Production Research, 52(1), 188-202 http://dx.doi.org/10.1080/00207543.2013.831190.

Mehrtens, J., Cragg, P., \& Mills, A. (2001). A model of Internet adoption by SMEs. Information Management, 39(3), 165176 http://dx.doi.org/10.1016/s0378-7206(01)00086-6.

Mirchandani, D., \& Motwani, J. (2001). End-user perceptions of ERP systems: a case study of an international automotive supplier. IJATM, 1(4), 416 http://dx.doi.org/10.1504/ijatm.2001.000049.

Montalvo, C. (2008). General wisdom concerning the factors affecting the adoption of cleaner technologies: a survey 1990-2007. Journal of Cleaner Production, 16(1), S7-S13 http://dx.doi.org/10.1016/j.jclepro.2007.10.002. 
Montazemi, A., \& Qahri-Saremi, H. (2015). Factors affecting adoption of online banking: A meta-analytic structural equation modelling study. Information Management, 52(2), 210-226 http://dx.doi.org/10.1016/j.im.2014.11.002.

Moore, G., \& Benbasat, I. (1991). Development of an Instrument to Measure the Perceptions of Adopting an Information Technology Innovation. Information Systems Research, 2(3), 192-222 http://dx.doi.org/10.1287/isre.2.3.192.

Noorul Haq, A., \& Kannan, G. (2006). Design of an integrated supplier selection and multi-echelon distribution inventory model in a built-to-order supply chain environment. International Journal of Production Research, 44(10), 1963-1985 http://dx.doi.org/10.1080/00207540500381427.

Noppers, E., Keizer, K., Bockarjova, M., \& Steg, L. (2015). The adoption of sustainable innovations: The role of instrumental, environmental, and symbolic attributes for earlier and later adopters. Journal of Environmental Psychology, 44, 74-84 http://dx.doi.org/10.1016/j.jenvp.2015.09.002.

Pardeshi, V. (2014). Architecture and Adoption Model for Cloud in Higher Education: Indian Perspective. Bonfring International Journal of Industrial Engineering and Management Science, 4(2), 43-47 http://dx.doi.org/10.9756/bijiems 4741.

Pham, T., \& Ho, J. (2015). The effects of product-related, personal-related factors and attractiveness of alternatives on consumer adoption of NFC-based mobile payments. Technology in Society, 43, 159-172 http://dx.doi.org/10.1016/j. techsoc.2015.05.004

Pine, B., \& Gilmore, J. (1999a). The experience economy. Boston: Harvard Business School Press.

Pine, B., \& Gilmore, J. (1999b). The experience economy. Boston: Harvard Business School Press.

Poon, S., \& Swatman, P. (1999). A Longitudinal Study of Expectations in Small Business Internet Commerce. International Journal of Electronic Commerce, 3(3), 21-33 http://dx.doi.org/10.1080/10864415.1999.11518339.

Porter, W., \& Graham, C. (2015). Institutional drivers and barriers to faculty adoption of blended learning in higher education. British Journal of Educational Technology, 47(4), 748-762 http://dx.doi.org/10.1111/bjet.12269.

Rai, V., \& Robinson, S. (2015). Agent-based modelling of energy technology adoption: Empirical integration of social, behavioral, economic, and environmental factors. Environmental Modelling \& Software, 70, 163-177 http://dx.doi. org/10.1016/j.envsoft.2015.04.014.

Rampersad, G., Plewa, C., \& Troshani, I. (2012). Investigating the use of information technology in managing innovation: A case study from a university technology transfer office. Journal of Engineering and Technology Management, 29(1), 3-21 http://dx.doi.org/10.1016/j.jengtecman.2011.09.002.

Regibeau, P., \& Rockett, K. (1996). The timing of product introduction and the credibility of compatibility decisions. International Journal of Industrial Organization, 14(6), 801-823 http://dx.doi.org/10.1016/0167-7187(95)01001-7.

Rogers, E. (1983). Diffusion of innovations (1st ed.). New York: Free Press.

Rogers, E. (2003). Diffusion of innovations. New York: Free Press.

Rogers, E. (2004). A Prospective and Retrospective Look at the Diffusion Model. Journal of Health Communication, 9(S1), 13-19 http://dx.doi.org/10.1080/10810730490271449.

Rogers, E., \& Shoemaker, F. (1971). Communication of Innovations A Cross-Cultural Approach (1st ed.). The Free Press.

Saaty, T. L. (1980). The Analytic Hierarchy Process. New York: McGraw-Hill.

Saaty, T. L. (1996). Decision Making for Leaders; The Analytical Hierarchy Process for Decisions in a Complex World. Pittsburgh: RWS Publications

Saaty, T. L. (2000). The Analytic Hierarchy Process. Pittsburgh: RWS Publications.

Saaty, T. (2008). Decision making with the analytic hierarchy process. International Journal of Services Sciences, 1(1), 83 http://dx.doi.org/10.1504/ijssci.2008.017590.

Sabi, H., Uzoka, F., Langmia, K., \& Njeh, F. (2016). Conceptualizing a model for adoption of cloud computing in education. International Journal of Information Management, 36(2), 183-191 http://dx.doi.org/10.1016/j.ijinfomgt. 2015.11.010.

Sambasivan, M., \& Fei, N. (2008). Evaluation of critical success factors of implementation of ISO 14001 using analytic hierarchy process (AHP): a case study from Malaysia. Journal of Cleaner Production, 16(13), 1424-1433.

Sanni, S., Ngah, Z., Karim, N., Abdullah, N., \& Waheed, M. (2013). Using the Diffusion of Innovation Concept to Explain the Factors That Contribute to the Adoption Rate of E-journal Publishing. Serials Review, 39(4), 250-257 http://dx. doi.org/10.1016/j.serrev.2013.10.001.

Sarpong, D., Dong, S., \& Appiah, G. (2016). Vinyl never say die': The re-incarnation, adoption and diffusion of retrotechnologies. Technological Forecasting and Social Change, 103, 109-118 http://dx.doi.org/10.1016/j.techfore.2015.10.012

Schiffman, L., \& Kanuk, L. L. (2004a). Consumer Behavior. New Jersey: Prentice Hall.

Schiffman, L. G., \& Kanuk, L. L. (2004b). Consumer behavior (6th ed.). Upper Saddle River: Pearson Prentice Hall.

Seyal, A., \& Rahman, M. (2003). A Preliminary Investigation of E-Commerce Adoption in Small \& Medium Enterprises in Brunei. Journal Of Global Information Technology Management, 6(2), 6-26 http://dx.doi.org/10.1080/1097198x.2003. 10856347.

Shen, G., Lin, W., Chen, Y., Yue, D., Liu, Z., \& Yang, C. (2015). Factors influencing the adoption and sustainable use of clean fuels and cookstoves in China -a Chinese literature review. Renewable and Sustainable Energy Reviews, 51, 741-750 http://dx.doi.org/10.1016/..rser.2015.06.049.

Singh, O., Anand, A., Kapur, P., \& Aggrawal, D. (2012). Consumer behaviour-based innovation diffusion modelling using stochastic differential equation incorporating change in adoption rate. International Journal of Technology Marketing, 7(4), 346 http://dx.doi.org/10.1504/ijtmkt.2012.049592.

Solomon, M. (2002). Consumer behaviour (1). Harlow[etc.]: Prentice-Hall.

Solomon, M. (2009). The truth about what customers want. Upper Saddle River, N.J: FT Press.

Srivastava, A., \& Lee, H. (2005). Predicting order and timing of new product moves: the role of top management in corporate entrepreneurship. Journal of Business Venturing, 20(4), 459-481 http://dx.doi.org/10.1016/j.jbusvent.2004. 02.002 .

Stockdale, R., \& Standing, C. (2006). A classification model to support SME e-commerce adoption initiatives. Journal of Small Business and Enterprise Development, 13(3), 381-394 http://dx.doi.org/10.1108/14626000610680262.

Tidd, J. (2001). Innovation management in context: environment, organization and performance. International Journal Of Management Reviews, 3(3), 169-183 http://dx.doi.org/10.1111/1468-2370.00062. 
Tidd, J. (2010). Gaining momentum. London: Imperial College Press.

Tidd, J., Bessant, J., \& Pavitt, K. (1997). Managing innovation. Chichester, Angleterre: J. Wiley.

Toffler, A. (1970). Future shock. London: Pan Books.

Tony Ke, T., Max Shen, Z., \& Li, S. (2013). How Inventory Cost Influences Introduction Timing of Product Line Extensions. Production And Operations Management, n/a-n/a. http://dx.doi.org/10.1111/j.1937-5956.2012.01425.x.

Trang, S., Zander, S., de Visser, B., \& Kolbe, L. (2016). Towards an importance-performance analysis of factors affecting ebusiness diffusion in the wood industry. Journal of Cleaner Production, 110, 121-131 http://dx.doi.org/10.1016/j. jclepro.2015.05.051.

Tsai, J., \& Hung, S. (2014). A novel model of technology diffusion: System dynamics perspective for cloud computing Journal of Engineering and Technology Management, 33, 47-62 http://dx.doi.org/10.1016/j.jengtecman.2014.02.003.

Udoh, E. (2012). Technology Acceptance Model Applied to the Adoption of Grid and Cloud Technology. International Journal of Grid And High Performance Computing, 4(1), 1-20 http://dx.doi.org/10.4018/jghpc.2012010101.

Valente, T., \& Rogers, E. (1995). The Origins and Development of the Diffusion of Innovations Paradigm as an Example of Scientific Growth. Science Communication, 16(3), 242-273 http://dx.doi.org/10.1177/1075547095016003002.

Vasseur, V., \& Kemp, R. (2015). The adoption of PV in the Netherlands: A statistical analysis of adoption factors. Renewable and Sustainable Energy Reviews, 41, 483-494 http://dx.doi.org/10.1016/j.rser.2014.08.020.

Venkatesh, V., Morris, M. G., Davis, G. B., \& Davis, F. D. (2003). User acceptance of information technology: Toward a unified view. MIS Quarterly, 27(3), 425-478.

Venkatesh, V., Speier, C., \& Morris, M. (2002). User Acceptance Enablers in Individual Decision Making About Technology: Toward an Integrated Model. Decision Sciences, 33(2), 297-316 http://dx.doi.org/10.1111/j.1540-5915.2002.tb01646.x.

Walitzer, K., Dermen, K., Barrick, C., \& Shyhalla, K. (2015). Modeling the Innovation-Decision Process: Dissemination and Adoption of a Motivational Interviewing Preparatory Procedure In Addiction Outpatient Clinics. Journal of Substance Abuse Treatment, 57, 18-29 http://dx.doi.org/10.1016/j.jsat.2015.04.003.

Wang, Y., Li, H., Li, C., \& Zhang, D. (2016). Factors affecting hotels' adoption of mobile reservation systems: A technology-organization-environment framework. Tourism Management, 53, 163-172 http://dx.doi.org/10.1016/j. tourman.2015.09.021.

Winer, R. (2000). Marketing management. Upper Saddle River: Prentice Hall.

Winer. (2007). Marketing Management (3rd ed.). Prentice Hall.

Wu, I., \& Chiu, M. (2015). Organizational applications of IT innovation and firm's competitive performance: A resourcebased view and the innovation diffusion approach. Journal of Engineering and Technology Management, 35, 25-44 http://dx.doi.org/10.1016/j.jengtecman.2014.09.002.

Zhu, Q., Sarkis, J., \& Lai, K. (2012). Green supply chain management innovation diffusion and its relationship to organizational improvement: An ecological modernization perspective. Journal of Engineering and Technology Management, 29(1), 168-185 http://dx.doi.org/10.1016/j.jengtecman.2011.09.012.

Zikmund, W., \& D'Amico, M. (1993). Instructor's manual to accompany Marketing (1). Minneapolis/St. Paul, Minn.: West Pub. Co.

Zikmund, W., McLeod, R., \& Gilbert, F. (2003). Customer relationship management. Hoboken: Wiley.

Submit your manuscript to a SpringerOpen ${ }^{\circ}$ journal and benefit from:

- Convenient online submission

- Rigorous peer review

Open access: articles freely available online

- High visibility within the field

Retaining the copyright to your article

Submit your next manuscript at $>$ springeropen.com 